\title{
SV-IV Peptide I-16 reduces coagulant power in normal Factor $V$ and Factor V Leiden
}

\author{
Biagio Di Miccoㄹ, Marilena Lepretti², Lidia Rota33, Ilaria Quaglia3, \\ Paola Ferrazzi ${ }^{3}$, Gianluca Di Micco ${ }^{2}$ and Pierpaolo Di Micco*4,5
}

\begin{abstract}
Address: ${ }^{1}$ University of Sannio Benevento Italy, ${ }^{2}$ Department of Biochemistry and Biophysics, Second University of Naples, Italy, ${ }^{3}$ Thrombosis Center, Istituto Clinico Humanitas, Milan, Italy, ${ }^{4}$ Department of Internal Medicine, Buon Consiglio Fatebenefratelli Hospital of Naples, Italy and ${ }^{5}$ Department of Biochemistry and Biotechnology and CEINGE, "Federico II" University of Naples, Italy

Email: Biagio Di Micco - biagio.dimicco@fastwebnet.it; Marilena Lepretti - dott_pie@libero.it; Lidia Rota - lidia.rota@humanitas.it; Ilaria Quaglia - ilaria.quaglia@humanitas.it; Paola Ferrazzi - paola.ferrazzi@humanitas.it; Gianluca Di Micco - gdimicco@inwind.it; Pierpaolo Di Micco* - pdimicco@libero.it

* Corresponding author
\end{abstract}

Published: 2I December 2007

Journal of Translational Medicine 2007, 5:69 doi:10.1 I86/1479-5876-5-69

This article is available from: http://www.translational-medicine.com/content/5/1/69

(C) 2007 Di Micco et al; licensee BioMed Central Ltd.

This is an Open Access article distributed under the terms of the Creative Commons Attribution License (http://creativecommons.org/licenses/by/2.0), which permits unrestricted use, distribution, and reproduction in any medium, provided the original work is properly cited.
Received: 29 September 2007

Accepted: 21 December 2007

\begin{abstract}
Native Factor $V$ is an anticoagulant, but when activated by thrombin, Factor $X$ or platelet proteases, it becomes a procoagulant. Due to these double properties, Factor $\mathrm{V}$ plays a crucial role in the regulation of coagulation/anticoagulation balance.

Factor $\mathrm{V}$ Leiden (FVL) disorder may lead to thrombophilia. Whether a reduction in the activation of Factor $V$ or Factor $V$ Leiden may correct the disposition to thrombophilia is unknown. Therefore we tested SV-IV Peptide I-16 (i.e. a peptide derived by seminal protein vescicle number IV, SV-IV) to assess its capacity to inhibit the procoagulant activity of normal clotting factor $V$ or Factor $V$ Leiden (FVL). We found that SV-IV protein has potent anti-inflammatory and immunomodulatory properties and also exerts procoagulant activity. In the present work we show that the SV-IV Peptide I-16, incubated with plasma containing normal Factor V or FVL plasma for 5 minutes reduces the procoagulant capacity of both substances. This is an anticoagulant effect whereas SV-IV protein is a procoagulant. This activity is effective both in terms of the coagulation tests, where coagulation times are increased, and in terms of biochemical tests conducted with purified molecules, where Factor $X$ activation is reduced.
\end{abstract}

Peptide I-16 was, in the pure molecule system, first incubated for 5 minutes with purified Factor $V$ then it was added to the mix of phosphatidylserine, $\mathrm{Ca}^{+}$, Factor $\mathrm{X}$ and its chromogenic molecule Chromozym X. We observed a more than $50 \%$ reduction in lysis of chromogenic molecule Chromozym $X$ by Factor $X a$, compared to the sample without Peptide 1-16. Such reduction in Chromozym $X$ lysis, is explained with the reduced activation of Factor $X$ by partial inactivation of Factor $V$ by Peptide $I-16$. Thus our study demonstrates that Peptide $I-16$ reduces the coagulation capacity of Factor $V$ and Factor $V$ Leiden in vitro, and, in turn, causes factor $X$ reduced activation.

\section{Introduction}

We have recently studied the Protein SV-IV (Seminal vesi- cle protein number IV) [1-3]. According to its mobility in SDS/PAGE, SV-IV protein is a basic, thermostable, secre- 
tory protein of low molecular weight (9758 d) and it is synthesized by the epithelium of a rat seminal vesicle (SV) under strict androgen transcriptional control [1-4]. SV-IV immunorelated proteins have been found in several rat tissues (uterus, lung, liver, brain and so on), and in human seminal fluid secretion. The amino acids sequence of Protein SV-IV is 90 amino-acids long and is encoded by a gene that has been identified, sequenced and expressed in Escherichia coli [5-9].

We found that SV-IV Protein has potent anti-inflammatory and immunomodulatory properties and also exerts procoagulant activity [4,10-15]. We sought to find a correlation between a function of the molecule and its structure and to assess if portions of the protein, fragments or peptides, individually tested, would reveal one or more of the molecule's reported functions [4,10-15]. We already showed that the fragment 1-70 of SV-IV is responsible for the procoagulant function of the molecule [14-18]. We decided to study a small segments of such fragment 1-70 in order to assess which sequence was specifically responsible of its activity $[4,17]$. We synthesised small peptides such as SV-IV Peptide 1-8, Peptide 8-16 and Peptide 116 of the fragment 1-70 [4].

Factor V is synthesized by megacaryocites, endothelial cells and hepatocytes. Native Factor V is an anticoagulant, but when activated by thrombin, Factor X or platelet proteases, it becomes a procoagulant. Physiologically, it can be activated by Factor X activated (Xa) and platelet proteases but usually it is largely activated by thrombin, so Factor V becomes Factor V activated (Va) [19]. It is a large protein with a molecular weight of $300.000 \mathrm{~d}$. Factor V binds the phospholipids of cellular membranes, such as platelets, endothelial cells, and monocytes, in the presence of calcium, and forms a receptor for Factor X and Prothrombin [20,21]. This last complex, named Prothrombinase, is responsible for cleaving prothrombin to form thrombin. This complex is much more efficient than Factor Xa alone in the prothrombin conversion. The native (i.e. inactivated) Factor V, however, is an anticoagulant. Native Factor V and Protein S are synergistic co-factors in the anticoagulant-inhibitory action of the activated Protein C $[19,21]$, which inhibits coagulation by breaking down Factor Va (i.e. after its activation) and Factor VIIIa thus leading to a slow thrombin generation.

When activated, Factor V loses this anticoagulant property [19]. Consequently, due to its double properties in its native and activated forms, Factor $\mathrm{V}$ plays a relevant role in coagulation/anticoagulation balance [4,19]. Should Factor V anticoagulant capacity be utilised, it would be sufficient to inhibit or reduce the activation of Factor $\mathrm{V}$.
Factor V Leiden (FVL) is a gene variant of clotting Factor V and it is responsible for the major forms of activated Protein $\mathrm{C}$ resistance. The structural difference of normal Factor $\mathrm{V}$ compared to Factor $\mathrm{V}$ Leiden consists in $\mathrm{a}$ substitution of an Arg with Gln in position 506, that is responsible for FVL absent lysis by the activated Protein $\mathrm{C}$, but as far as factor $\mathrm{X}$ activation is concerned they are comparable [19-21]. The absent lysis in FVL causes thrombophilia by activating Factor $\mathrm{X}$, therefore leading to an increase of the procoagulant potency, because normal Factor $\mathrm{V}$ is joined with FVL, that has not been broken down by activated Protein $\mathrm{C}$. Therefore, we tried to reduce the procoagulant activity of normal Factor Va and also of FVL activated by Peptide1-16. Then, we also evaluated the activities of Peptide1-16 incubated with plasma containing normal Factor V or FVL in diversified coagulation systems in vitro and $\backslash$ or incubated with Factor $\mathrm{V}$ in a system of pure molecules.

\section{Methods}

INBIOS Company, via Olivetti 1, Pozzuoli, Naples, Italy provided the organic synthesis on solid phase of SV-IV Peptide 1-16, since now is well known amino acid sequence of Protein SV-IV. The amino acids sequence is RKTKEKYSQSEEVVSE. The Thrombosis Center of the Istituto Clinico Humanitas, via Manzoni 56, Rozzano, Milan, Italy and the Department of Internal Medicine of the Buon Consiglio Fatebenefratelli Hospital of Naples provided plasma samples taken from twelve patients carriers of FVL.

Selected patients carriers of FVL were affected by previous thrombotic disease except 2 subjects that had not experienced any thrombotic manifestation in their anamnesis and that have been monitored for a couple of years.

Blood samples were obtained by venipuncture from antecubital vein and collected in sodium citrate $0.11 \mathrm{M}$ tubes in 9:1 v $\backslash \mathrm{v}$ in three aliquots of $5 \mathrm{~mL}$ and also in EDTA in one aliquot of $5 \mathrm{~mL}$ from all subjects.

All samples were tested to confirm the presence of FVL in order to confirm the thrombophilic state. The presence of FVL was confirmed with DNA extraction from the sample in EDTA and using the "NUCLEON BACC" kit (Amershan, Germany); Factor V G1691A gene polymorphism (i.e. FVL) was researched using PCR amplification with specific primers and the Light Cycler apparatus (Roche, Milan, Italy). Behring Institute (Protein $C$ reagent, Dade Bhering, Milan, Italy) provided the kit to assess resistance to activated Protein C, which is altered in carrier of FVL as it contains Agkistrodom Contortix venom as the Protein $\mathrm{C}$ activator. 
The activated partial thromboplastin time (aPTT) reagent (Ellagic acid and phospholipids) necessary for aPTT technique was also provided by Bhering Institute (Thromboplastin time, Milan, Italy).

Sigma, Milan, Italy, provided Factor $\mathrm{V}$ deficient plasmas, purified Factor V, purified Factor X, Phosphatidylserine and Chromozym X (Human Factor V deficient plasma, Sigma, Milan, Italy; Human Plasma Factor V, Sigma, Milan, Italy; Human Plasma Factor X, Sigma, Milan, Italy; Phosphatidylserine, Sigma, Milan, Italy; Chromozyn X, Sigma, Milan, Italy, respectively).

Once obtained all materials we developed study techniques to assess possible interference of Peptide 1-16 with Factor $V$ and Factor $V$ Leiden. We had to prove before the factor $\mathrm{V}$ activation to factor Va: in pure molecules factor $\mathrm{V}$, phosphatidylserine, $\mathrm{Ca} 2^{+}$and factor $\mathrm{X}$ system, we attempted to obtain factor $\mathrm{X}$ activation to factor Xa by factor $\mathrm{V}$ activation to $\mathrm{Va}$; we have varied the physiological concentrations, increasing some component concentration of the system: phosphatidylserine, not phospholipid complex, and factor $\mathrm{X}$ increased concentration, because we have further coactivators lacking in vitro. After testing the 50 or 5 or $1 \mu \mathrm{M}$ peptide $1-16$ concentractions both with plasmas and pure molecules we noted that $1 \mathrm{mM}$ not produced variation whereas 50 and $5 \mu \mathrm{M}$ produced same variations and both the concentrations required the incubation time of 5 minutes. Here we report the reagents used to perform the in vitro's experiences.

1) $\mathrm{NaCl}$ solution: $0,15 \mathrm{M}$

2) $\mathrm{CaCl} 2$ solution: $25 \mathrm{mM}$

3) aPTT reagent (phospholipids plus ellagic acid from the kit)

4) Peptide 1-16 solution: $50 \mu \mathrm{M}$

5) Factor V solution: $16,6 \mu \mathrm{M}$; concentration in tests 0,166 $\mu \mathrm{M}$

6) Factor X solution: $61 \mu \mathrm{M}$;

7) Phosphatidylserine solution: $12,5 \mu \mathrm{g} / \mu \mathrm{L}$

8) solution of Chromozym X substrate: 1,9 mM.

Experimental tests were performed by several study techniques:

* coagulative technique
* biochemical technique (conducted with purified molecules)

Coagulation techniques included the aPTT test technique, performed using factor $\mathrm{V}$ deficient plasma and purified Factor $\mathrm{V}$; moreover a further coagulation technique was performed with Leiden plasmas compared to normal plasmas when incubated with Peptide $1-16$ or $\mathrm{NaCl}$ as control.

A volume of $50 \mu \mathrm{l}$ of aPTT reagent's was added to $100 \mu \mathrm{l}$ of Factor $\mathrm{V}$ deficient plasmas and was incubated at $37^{\circ} \mathrm{C}$ for 1 minute and then $10 \mu$ l of purified Factor $V$ incubated with $7 \mu$ of Peptide $1-16$ or $7 \mu$ of $\mathrm{NaCl}$ for 5 minutes; then $100 \mu \mathrm{l} \mathrm{CaCl} 2$ was added and the coagulation time was recorded.

Coagulation techniques were also performed with Leiden plasma incubated for 5 minutes with Peptide 1-16 or $\mathrm{NaCl}$; to $100 \mu \mathrm{l}$ Leiden plasma plus $7 \mu \mathrm{l}$ Peptide $1-16$ or $\mathrm{NaCl}$ incubated for 5 minutes was added $50 \mathrm{mcl}$ aPTT reagent and, after incubation for 1 minutes, was furtherly added $100 \mu \mathrm{l} \mathrm{CaCl} 2$; then the coagulation time was registered. Thereafter the same procedure were performed with normal plasma: we incubated normal plasma for 5 minutes with Peptide $1-16$ or $\mathrm{NaCl}$; to $100 \mu \mathrm{l}$ normal plasma plus $7 \mu$ Peptide $1-16$ or $\mathrm{NaCl}$ incubated for 5 minutes was added $50 \mu \mathrm{l}$ aPTT reagent and after 1 minute, we added $100 \mu \mathrm{l}$ of $\mathrm{CaCl} 2$, then the coagulation time was registered again. We chose to incubate the peptide 1-16 with purified factor $\mathrm{V}$ or normal or Leiden plasma for $5 \mathrm{~min}$ utes because the incubation for 5 or 7 or 9 minutes gave the same results in previous experiences (data not shown). Five tests were conducted on each plasma sample and the result was given as media with SD for all performed tests.

Biochemical techniques with pure molecules aimed to carry out Factor X activation by Factor Va. For Factor X activation, Factor V and FVL operate in the same way. Once activated, Factor $\mathrm{X}$ breaks down its chromogenic substrate Chromozym X. The scission of the Chromozym $\mathrm{X}$ produces a coloured molecule and its concentration and colour depended directly on the concentration of activated Factor $\mathrm{X}$. The activation of Factor $\mathrm{V}$ to $\mathrm{Va}$, that actives Factor $\mathrm{X}$ has been obtained with incubation of phosphatidylserine and $\mathrm{Ca} 2^{+}$, and then added to Factor X.

The final concentrations of used molecules are shown below:

$10 \mu$ l Phosphatidylserine (100 ng) and $10 \mu \mathrm{l}$ of purified Factor $\mathrm{V}(0,02 \mu \mathrm{M})$ and $\mathrm{CaCl} 2$, then incubated at $37^{\circ} \mathrm{C}$ for 3 minutes. Then the process was: $10 \mu$ l Phosphatidylserine added to $10 \mu \mathrm{l}$ of purified Factor $\mathrm{V}$ added to $\mathrm{CaCl} 2$ 
added to $20 \mu \mathrm{l}$ of purified Factor $\mathrm{X}(12,2 \mu \mathrm{M})$ and incubated at $37^{\circ} \mathrm{C}$ for 3 minutes. Thereafter, a volume of $1,120 \mu \mathrm{l} \mathrm{NaCl}(0,15 \mathrm{mM})$ was added to $20 \mu \mathrm{l}$ of Chromozym $X$. OD readings were taken at $405 \mathrm{~nm}$ after 15 minutes in order to know the Chromozym X lysis. Obtained values were recorded as control value of Chromozym X lysis.

We substitute Peptide 1-16 to $\mathrm{NaCl}$ and we tested the incubation of the mixture of purified Factor V with Peptide 1-16 for 5 minutes; this mix was then added to the phosphatidylserine, $\mathrm{CaCl} 2$ and factor $\mathrm{X}$ mixture and incubated for 3 minutes. Then, Chromozym $X$ was added and OD readings were taken at $405 \mathrm{~nm}$ after 15 minutes incubation. Obtained values were recorded as results of the inhibiting clotting activities of peptide 1-16 against purified factor $\mathrm{V}$.

Five tests were conducted on each samples. Result represent the media with SD of all performed tests.

\section{Statistical analysis}

Statistical analysis was based on the one way analysis of variance (ANOVA); differences were considered to be significant if $\mathrm{p}$ was $<0.05$. Statistical analysis were carried out using SPSS statistical software.

\section{Results}

The coagulation time of aPTT test of normal plasmas and plasmas containing FVL and aPTT reagent plus $\mathrm{NaCl}$ and $\mathrm{CaCl} 2$ was normal and no differences were found between normal plasmas and Leiden plasmas: $36+\backslash-3$ seconds and $37+/-2$ seconds respectively (data not shown). No differences were found between aPTT of normal plasmas and Leiden plasmas at time T0, when we performed the incubation with peptide $1-16$ or $\mathrm{NaCl}$ (respectively $40+/-5$ seconds and $38+/-3$ seconds); when we incubated the Peptide 1-16 with normal or Leiden plasmas for 5 minutes, the coagulation time turned respectively to $96+/-6$ seconds and $100+\mid-5$ seconds reaching statistical significance $(96+/-6$ seconds versus $38+/-3$ seconds, $\mathrm{p}:<0.001, \mathrm{~s}$; and $100+/-5$ seconds versus $38+/-5$ seconds, p: 0.001 , s) (Table 1 ).

Moreover, the coagulation time was also obtained by the aPTT test with deficient Factor V plasma and purified Factor $\mathrm{V}$ incubated with $\mathrm{NaCl}$ or Peptide 1-16 for 5 minutes plus aPTT reagent (Ellagic acid and phospholipids) and $\mathrm{CaCl} 2$. When we incubated $\mathrm{NaCl}$, the coagulation time was normal: $35+\mid-4$ seconds and $39+/-4$ seconds respectively; when the Peptide 1-16 substituted $\mathrm{NaCl}$, the coagulation time was significantly longer: $96+\backslash-7$ seconds, p: $<0.001$ (Table 2).

As control of previous experiments, in the biochemical tests, purified Factor V activation was obtained by the incubation for 3 minutes with phosphatidilserine, $\mathrm{CaCl} 2$, in presence of factor X with Chromozym $\mathrm{X}$, and $\mathrm{NaCl}$ (as control of next tests) in order to activate Factor $\mathrm{X}$ with pure molecules: the Factor $\mathrm{X}$ incubated for 3 minutes and Chromozym X, incubated for 15 minutes. We obtained a coloured product with an optical density (O.D.) of 0.420 $\mathrm{nm}$. On the other hand, when we incubated Factor $V$ with Peptide1-16 (instead of $\mathrm{NaCl}$ ) for 5 minutes and then added to the mixture of phospatidilserine and $\mathrm{CaCl} 2$ with subsequent addition of factor $\mathrm{X}$ and Chromozym $\mathrm{X}$, we obtained a significantly different optical density (O.D.) of $0.190 \mathrm{~nm}, \mathrm{p}:<0.0001$, s (Table 3).

\section{Discussion}

Whether factor $V$ has sufficient endogenic activity to allow small amount factor Xa generation is still a matter of debate [22]. Data from literature report that factor V circulates as a single chain protein with about $0.27 \%$ of proteolitic activity comparable to Va [23]. Foster et al.[24] postulate that factor $\mathrm{V}$ appears to be a procofactor with 1 /

Table I: aPTT coagulation time of normal plasma and Leiden plasma (100 $\mu \mathrm{L})$ with and without incubation for 5 minutes with peptide I-16 or $\mathrm{NaCl}$ as control.

\begin{tabular}{lclc}
\hline $\begin{array}{l}\text { Plasmas incubated with } \\
\text { peptide I-16 }\end{array}$ & $\begin{array}{c}\text { aPTT coagulation } \\
\text { time (sec.) }\end{array}$ & $\begin{array}{l}\text { Plasmas incubated } \\
\text { with NaCl }\end{array}$ & $\begin{array}{c}\text { aPTT coagulation } \\
\text { time (sec.) }\end{array}$ \\
\hline $\begin{array}{l}\text { Normal plasma incubated at T0 } \\
\text { with peptide I-16 } \\
\text { Leiden plasma incubated at T0 with }\end{array}$ & $40 \pm 5$ & $\begin{array}{l}\text { Normal plasma incubated at } \\
\text { T0 with NaCl } \\
\text { Leiden plasma incubated at }\end{array}$ & $38 \pm 3$ \\
$\begin{array}{l}\text { Peptide I-16 } \\
\text { Normal plasma incubated with }\end{array}$ & $4 I \pm 4$ & $\begin{array}{l}\text { T0 with NaCl } \\
\text { Normal plasma incubated at }\end{array}$ & $30 \pm 4$ \\
$\begin{array}{l}\text { peptide I-16 at TI } \\
\text { Leiden plasma incubated at TI with }\end{array}$ & $90 \pm 6$ & $\begin{array}{l}\text { TI with NaCl } \\
\text { Leiden plasma incubated at }\end{array}$ & $38 \pm 3$ \\
Peptide I-16 & $120 \pm 9$ & TI with NaCl & 0,16 \\
\hline
\end{tabular}

aPTT: activated partial thromboplastin time sec.: seconds

TO: time of incubation

TI: 5 minutes after the incubation

$\mathrm{NaCl}$ : sodium clorure 
Table 2: aPTT coagulation time of deficient factor $V$ plasma added to purified factor $V(100 \mu L)$ and incubated with peptide $I-16$ or $\mathrm{NaCl}$ as control.

\begin{tabular}{|c|c|c|c|c|}
\hline Test & $\begin{array}{l}\text { aPTT coagulation } \\
\text { time (sec.) }\end{array}$ & Test & $\begin{array}{l}\text { aPTT coagulation } \\
\text { time (sec.) }\end{array}$ & $\mathbf{p}$ \\
\hline $\begin{array}{l}\text { Deficient factor } \mathrm{V} \text { plasma } \\
\text { added to purified factor } \mathrm{V} \\
\text { and } \mathrm{NaCl}\end{array}$ & $36 \pm 4$ & $\begin{array}{l}\text { Deficient factor } V \text { plasma } \\
\text { added to purified and } \\
\text { peptide } 1-16\end{array}$ & $119 \pm 7$ & 0,000 \\
\hline
\end{tabular}

aPTT: activated partial thromboplastin time

sec.: seconds

$\mathrm{NaCl}$ : sodium clorure

400 the activity of full activated factor $\mathrm{V}$ (i.e. factor Va). The proteolytic conversion of factor $\mathrm{V}$ to factor $\mathrm{Va}$ is catalysed by thrombin and Xa. However, because factor Va is required for thrombin generation, the initial participation of factor $\mathrm{V}$ in the expression of prothrombinase activity is not well understood [24]. Orfeo et al. demonstrated [25] that prothrombinase complex consists of the protease factor $\mathrm{Xa}, \mathrm{Ca} 2$ and factor $\mathrm{V}$ assembled on phospholipid membrane. Factor Va functions both as a receptor for factor Xa and as a positive effector for factor Xa catalytic efficiency, thus being a key factor for an efficient conversion of prothrombin to thrombin. The activation of the procofactor factor $\mathrm{V}$ to factor $\mathrm{Va}$ is an essential reaction that occurs early in the process of tissue factor pathway, however the catalytic sequence leading to formation of factor $\mathrm{Va}$ is still a controversial issue [25]. We attempted, by a system consisting of pure molecules (i.e. factor $\mathrm{V}$, phosphatidylserine, Ca2 and factor $\mathrm{X}$ ) to obtain factor $\mathrm{X}$ activation to Xa through factor $\mathrm{V}$ activation to factor Va. We varied the physiological concentrations, increasing the same components of the system and chose to work only with phosphatidylserine and not phospholipid complex and to increase factor $\mathrm{X}$ concentration. This system produced factor X activation to Xa. We tested factor Xa peptidolytic activity with Chromozym $X$, that is a specific chromogenic molecule of factor Xa; when we added Chromozym $X$ to this system, it generated colour, indicating that factor $\mathrm{X}$ in our system became Xa. Then, we incubated purified factor $\mathrm{V}$ with Peptide 1-16 for 5 minutes, and thereafter we added it to the same mixture, in order to prove if this Peptide 1-16 hampers factor V activation. In this system, in fact, factor $\mathrm{X}$ activation is reduced, as demonstrated by reduced lysis of chromozym X.
FVL is an inherited condition leading to thrombophilia through the activated protein $\mathrm{C}$ resistance. In presence of FVL, the activated Protein C does not breakdown FVL, that accumulates so increasing the global coagulative power in the coagulative cascade and impairing the coagulation|anticoagulation balance. The results of our experiments demonstrate clearly that Peptide1-16 inhibits the activity both of FVL and of normal clotting factor $\mathrm{V}$, in particular its ability to activate Factor X. We demonstrated that the Leiden Plasmas incubated with the Peptide 1-16 cause an increase in the coagulation time in the test of aPTT, as reported in Table 1.

Data obtained by incubating Peptide $1-16$ with purified Factor $\mathrm{V}$ for 5 minutes, then added to factor $\mathrm{V}$ deficient plasma, confirmed such results. In fact when we added this mixture to deficient Factor V Plasmas in an aPTT test we found a prolonged coagulation time compared to control (i.e. with $\mathrm{NaCl}$ without peptide 1-16), as reported in Table 2.

Moreover, considering that in the Factor $\mathrm{X}$ activation, Factor $\mathrm{V}$ and FVL operate in the same way, to verify Factor $\mathrm{X}$ activation, we only tested the ability of purified Factor $\mathrm{V}$ activated by pure molecules as phosphatidilserine and $\mathrm{CaCl} 2$. Then we added this mixture to Factor $\mathrm{X}$ and Chromozym $X$, in order to cause the lysis of Chromozym $X$ by Xa: we obtained an optical density of $0.420 \mathrm{~nm}$ which clearly demonstrates the lysis of Chromozym X. Yet, if we incubate for 5 minutes Factor $V$ and Peptide 1-16 and we add them to the mixture of pure molecules (phosphatidilserine and $\mathrm{CaCl} 2$ ) and thereafter to Factor $\mathrm{X}$ and Chromozym X, we observed that Factor X activation caused a

Table 3: Factor $X$ activation test (O.D.): purified factor $V(0.002 \mu \mathrm{M})$ incubated with peptide I-16 or $\mathrm{NaCl}$ for 5 minutes and thereafter added to phosphatidilserine and $\mathrm{CaCl} 2$ and factor $\mathrm{X}$ and Chromozyn $\mathrm{X}$ for 15 minutes.

\begin{tabular}{lccc}
\hline Parameter & Mixture with NaCl & Mixture with peptide I-I6 & P \\
\hline O.D. $(\mathrm{nm})$ of Chromozyn X & $0.420 \pm 0.008$ & $0.190 \pm 0.006$ & 0,000
\end{tabular}

O.D.: optical density

$\mathrm{nm}$ : nanometers

$\mathrm{CaCl}$ : calcium clorure

$\mathrm{NaCl}$ : sodium clorure 
reduced lysis of Chromozym at an optical density of 0,190 $\mathrm{nm}$. Therefore, Factor $\mathrm{X}$ activation is significantly slower compared to control (i.e. $\mathrm{NaCl}$ and purified Factor $\mathrm{V}$ ), and this is confirmed by a reduced lysis of Chromozym X (i.e. O.D. =0.190).

The occurring contact of the two molecules, Factor $\mathrm{V}$ and Peptide1-16, is proved by the fact that both incubated at time 0 and added to phosphatidylserine and $\mathrm{CaCl} 2$ produced a different effect compared to that obtained if we incubate Factor V, alone for 5 minutes, without Peptide 116 . This suggests that the observed events were caused by the incubation of the two molecules and that 5 minutes are needed for their effective interaction. Our results indicate that Peptide 1-16 is not only an inhibitor of normal clotting factor V but also of FVL. So, Peptide 1-16 may represent an inhibitor of clotting cascade also in presence of inherited thrombophilic disorder leading to hypercoagulable state as FVL. We demonstrated, in fact, the inhibition of clotting cascade in presence of normal factor $\mathrm{V}$ and also in the presence of plasmas containing FVL by both coagulation techniques and $\backslash$ or biochemical approaches.

One may argue that in our studies we used purified factor $\mathrm{V}$ to test the normal cascade and FVL from plasma of subjects carrying this kind of alteration. However we point out that in biochemical tests, normal purified factor $\mathrm{V}$ alone was incubated with Peptide 1-16 while purified FVL was not incubated with Peptide 1-16 because purified FVL is not available commercially both for experimental studies and $\backslash$ or clinical approaches. Moreover it is really difficult to obtain purified FVL from plasma of subjects carrying this alteration. Yet, the presence of purified FVL is not necessary for our studies because the role of normal Factor $\mathrm{V}$ and Factor $\mathrm{V}$ Leiden in Factor X activation is comparable.

In conclusion, our study demonstrates that Peptide1-16 may represent a specific antagonist of FVL and one may envision its use in the thrombophilic FVL patients, should further studies confirm our results.

\section{Competing interests}

The authors declare that they have no competing interests, nor any financial supports during patients' selection, experimental tests and article extension.

\section{Authors' contributions}

BDM and ML performed all biochemical tests described in the paper with the exception of genetic tests for factor $\mathrm{V}$ Leiden gene variant; IQ and PF performed genetic test to identify factor V Leiden gene variant; LR, GDM and PDM performed patients' selection; PDM and BDM performed paper extension.

\section{Acknowledgements}

Authors like to thank Prof. Marco Romano, Second University of Naples, Italy, for his helpful support for English revision and dr. Mariateresa lannuzzo for her support to perform statistical analysis.

\section{References}

I. Ostrowski MC, Kistler MK, Kistler WS: Purification and cell-free synthesis of a major from rat seminal vesicle secretion. A potential marker for androgen action. I Biol Chem 1979, 254:383-390.

2. Mansson PE, Sugino A, Harris SE: Use of a cloned double stranded cDNA coding for a major androgen dependent protein in rat seminal vesicle secretion: the effect of testosterone in gene expression. Nucleic Acids Res 1981, 9:935-946.

3. Abrescia P, Corbo L, Metafora S: Maturation in different translational systems of the Protein SV-IV secreted from the rat seminal vesicle epithelium. Bull Mol Biol Med 1986, I I:19-33.

4. Ialenti A, Santagata V, Di Micco B, Carteni M, Stiuso P, Metafora V, Metafora S: Synthesis of novel anti-inflammatory peptides derived from the aminoacid sequenze of the bioactive protein SV-IV. Eur J Biochem 200I, 268:3399-3406.

5. Harris SE, Mansson PE, Tully DB, Burkhart B: Seminal vesicle secretion IV gene: allelic difference due to a series of 20 basepair direct tandem repeats within an intron. Proc Natl Acad Sci USA 1983, 80:6460-6464.

6. Kandala C, Kistler MK, Lawther RP, Kistler WS: Characterization of a genomic clone for rat seminal vesicle secretory protein IV. Nucleic Acids Res 1983, I I:3169-3 I86.

7. Pan YC, Li SSL: Structure of secretory protein IV from rat seminal vesicles. Int J Pept Protein Res 1982, 20(3): I77-187.

8. McDonald C, William L, McTurck P, Fuller F, Mclntosh E, Higgins S: Isolation and characterisation of genes for androgen-responsive secretory protein of rat seminal vesicles. Nucleic Acids Res 1983, II:917-930.

9. D'Ambrosio E, Del Grosso N, Ravagnan G, Peluso G, Metafora S: Cloning and expression of the rat genomic DNA sequence coding for the secreted form of the protein SV-IV. Bull Mol Biol Med 1993, 18:215-223.

10. Metafora S, Peluso G, Persico P, Ravagnan G, Esposito C, Porta R: Immunosuppressive and anti-inflammatory properties of a major protein secreted from the epithelium of the rat seminal vesicles. Biochem Pharmacol 1989, 38:|2|-|3|.

II. Metafora S, Porta R, Ravagnan G, Peluso G, Tufano MA, De Martino L, lanniello R, Galdiero F: Inhibitory effect of SV-IV, a major protein secreted from the rat seminal vesicle epithelium, on phagocytosis and chemotaxis of human polymorphonuclear leukocytes. J Leukocyte Biol 1989, 46:409-4I6.

12. Vuotto ML, Peluso G, Mancino D, Colonna G, Facchiano A, lelpo MT, Ravagnan G, Metafora S: Inhibition of interleukin-I release and activity by the rat seminal vesicle protein SV-IV. J Leukoc Biol 1993, 53(3):214-222.

13. Romano-Carratelli C, Galdiero M, Nuzzi I, Bentivoglio C, Porta R, Peluso G, Ravagnan G, Metafora S: In vivo inhibition of cell-mediated and humoral immune responses to cellular antigens by SV-IV, a major protein secreted from the rat seminal vesicle epithelium. J Reprod Immunol 1995, 28: I5-30.

14. Porta R, Esposito C, Schinina ME, Mancuso F, Marino G, Pucci P, Peluso G, Metafora S: Biological activities of CNBr fragments of a major protein secreted from the rat seminal vesicle epithelium. Int J Pept Protein Res 1994, 44(5):507-5 I 2.

15. Di Rosa M, Giroud JP, Willoughby DA: Studies of mediators of the acute inflammatory response induced in rats in different sites by carregeenin and turpentine. J Pathol I97I, 104:15-29.

16. Di Micco B, Colonna G, Porta R, Metafora S: Rat protein SV-IV accelerates human blood coagulation in vitro by selective inhibition of Antithrombin III. Biochem Pharmacol 1994, 48:345-352.

17. Di Micco B, Stiuso $P$, Colonna G, Porta R, Marchese $M$, Schininà MA, Macalello MA, Metafora S: A peptide derivative (I-70 fragment) of protein SV-IV accelerates human blood coagulation in vitro by selective competitive inhibition of the heparininduced antithrombin III activation process. J Pept Res 1997, 49:174- 182.

18. Di Micco B, Caen J, Colonna G, Macalello MA, Marchese M, Stiuso P, Di Micco P, Metafora S: Inhibition of Antithrombin by protein 
SV-IV normalizes the main coagulation parameters of hemophilic blood. Eur J Pharmacol 2000, 39 I: I-9.

19. Dahlback B: Physiological anticoagulation. Resistance to activated Protein $\mathbf{C}$ and venous thromboembolism. J Clin Invest 1994, 94:923-927.

20. Hathaway WE, Goodnight SH Jr: Prothrombin, Factor V, VII, $\mathbf{X}$ and combined Factor deficiencies. In Disorders of Hemostasis and Thrombosis - a clinical guide Edited by: Hathaway WE, Goodnight SH Jr. McGraw-Hill, Inc. New York; 1993:155-I66.

21. Borg JY: Déficit constitutionnels en facteur de la coagulation en dehors de I'Hemophilie. In Manuel d'Hémostase Edited by: Sanpol J, Arnoux D, Boutière B. Elsevier, Paris; 1995:359-377.

22. Nesheim ME, Taswell JB, Mann KG: The contribution of bovine factor $\mathrm{V}$ and factor $\mathrm{Va}$ to the activity of prothrombinase. J Biol Chem 1979, 254: 10952-10962.

23. Nemerson $Y$, Williams WJ: Biochimica dei fattori plasmatici della coagulazione. In Ematologia Edited by: Williams WJ, Beutler E, Erslev A], Lichtman MA. Mc Graw Hill Libri Italia; 1991:1310-1327. [Italian Edition]

24. Foster WB, Nesheim ME, Mann KG: The factor Xa-catalyzed activation of factor V. J Biol Chem 1983, 258: I3970-13977.

25. Orfeo T, Brufatto N, Nesheim ME, Hung Xu, Butenas S, Mann KG: The factor V activation paradox. J Biol Chem 2004, 279: 19580-19591.

Publish with Bio Med Central and every scientist can read your work free of charge

"BioMed Central will be the most significant development for disseminating the results of biomedical research in our lifetime. "

Sir Paul Nurse, Cancer Research UK

Your research papers will be:

- available free of charge to the entire biomedical community

- peer reviewed and published immediately upon acceptance

- cited in PubMed and archived on PubMed Central

- yours - you keep the copyright

Submit your manuscript here:

http://www.biomedcentral.com/info/publishing_adv.asp
BiolMedcentral 